"Addressing the challenges of food security and youth unemployment in South Africa through land reform policies"

\section{AUTHORS}

ARTICLE INFO

DOI

RELEASED ON

JOURNAL

FOUNDER

\section{Akwasi Arko-Achemfuor}

Akwasi Arko-Achemfuor (2016). Addressing the challenges of food security and youth unemployment in South Africa through land reform policies. Environmental Economics, 7(3), 52-59. doi:10.21511/ee.07(3).2016.06

http://dx.doi.org/10.21511/ee.07(3).2016.06

Friday, 21 October 2016

"Environmental Economics"

LLC "Consulting Publishing Company "Business Perspectives"

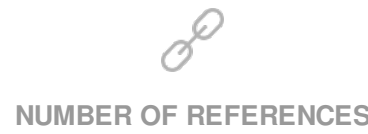

0
NUMBER OF FIGURES

0

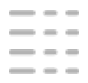

NUMBER OF TABLES

0

(C) The author(s) 2022. This publication is an open access article. 


\title{
Addressing the challenges of food security and youth unemployment in South Africa through land reform policies
}

\begin{abstract}
South Africa's past policy of apartheid has contributed to some of the socio-economic challenges the country faces today. Some of the challenges include grinding poverty levels, increasing inequality and unemployment among large sections of the population. The constitution of the country makes provision for property and land rights as strategies for addressing some of the past injustices, ensuring food insecurity and sustainable livelihoods. A number of polices have been drafted in this regard, but it is acknowledged that some of the policies that have been adopted by the government have not yielded the desired result leading to the fear that if the situation is not radically addressed may lead to unintended consequences. This paper assesses a number of polices, programs, approaches and strategies regarding land reform policies have that been put into place, most of which have not worked as expected including the fact that the youth have not been factored into most of these programs and policies. This article advocates for the youth to be factored into all land reform and food security policies and programs as a way of capacitating them and getting the youth to see agriculture as a career choice to ensure future food security for the nation, while at the same time addressing youth unemployment and rural poverty.
\end{abstract}

Keywords: land reform, youth, food security, livelihoods, development, policy.

JEL Classification: Q15, Q18, O2.

\section{Introduction}

South Africa's past policy of apartheid has contributed to some of the socio-economic challenges the country faces today. Some of the challenges include grinding poverty levels, increasing inequality and unemployment among large sections of the population. Recent media reports indicate that the official unemployment rate of South Africa stands at 25\%, but the broader definition; it is estimated at $37 \%$. South Africa is said to be one of the countries with the highest inequality levels in the world with a Gini coefficient of about 0.67. Poverty levels among a sizable proportion of the population are also very high. South Africa is home to the highest number of people living with the Human Immune Virus in the world. The youth is one of the groups that is mostly affected by most of the social-economic challenges in the country with rate of unemployment among the group at $70 \%$. Poverty levels are also very high among the South African youth especially the rural youth. In the rural areas where a lot of people depend on agriculture for their survival, access to land is a problem most especially for the youth. The Department of Rural Development and Land Reform (2012) points out that the 1913 Natives Land Act left a trail of devastation among South Africa's rural communities. It adds that the impact of the Natives Land Act has consigned some 12 million South Africans to live in poverty in rural areas. The constitution of the country makes provision for property and land rights as strategies

(c) Akwasi Arko-Achemfuor, 2016.

Akwasi Arko-Achemfuor, Dr., Department of ABET \& Youth Development, University of South Africa, South Africa. for addressing past injustices, ensuring food insecurity and sustainable livelihoods. The National Development Plan (NDP) (2012) advocates for the better integration of the country's rural areas into the national economy through land reform, infrastructure development, job creation and poverty alleviation. The vision of the NDP is to create one million jobs in the agriculture sector by expanding irrigated agriculture, using some of the underused land in communal areas and land reform projects for commercial production, pick and support commercial agriculture sectors and regions that have the highest potential for growth and employment and supporting job creation in the upstream and downstream industries, developing strategies that give new entrants access to product value chains and support from better-resourced players. A number of polices have been drafted in this regard, but it is acknowledged that some of the policies that have been adopted by successive post-apartheid governments have not yielded the desired result leading to the fear that if the situation is not radically addressed, it may lead to unintended consequences. Jacobs, Lahiff and Hall (2003) note that the land redistribution forms part of the government's land reform program, alongside restitution and tenure reform. They add that all aspects of South Africa's land reform derive from the constitution of South Africa. Some of the policies that have been adopted by South Africa in dealing with land reform include the entrenchment of and protection of private property rights and the "willing buyer willing seller" basis for land acquisition (Mwatwara, 2013). This article assesses some of the polices regarding land reform, the challenges they have encountered and proposes that the policies should 
factor the youth into all land reform programs as a way of capacitating them and getting them to see agriculture as a career choice to ensure future food security for the nation, while at the same time addressing youth unemployment and rural poverty. The South Africa Year Book (2010/11) indicates that one of the strategies that is being used by the Department of Rural Development and Land Reform is declaring War on Poverty (WoP) by assisting the rural poor to be self sufficient. The objective of the WoP program is to have positive impact on the lives of people, addressing poverty and hunger and ensuring that people take control of their destiny. As indicated earlier on in this article, land reform which comprises restitution, redistribution and tenure has not specifically targeted the South African youth in most of the programs to ensure food security as the older generation of white commercial farmers grow older, as well as addressing youth unemployment most especially in rural areas.

\section{Research methodology}

The documentary research method is used for this study as a concept paper. Documentary research method, according to Mogalakwe (2006), refers to the analysis of documents that contain information about the phenomenon we wish to study. Payne and Payne (2004) similarly concur with Mogalakwe by describing the documentary research method as the technique used to categorize, investigate, interpret and identify the limitations of physical sources, most commonly documents whether in the public or private domain. The use of this method for this paper is justified by the fact that this is a concept paper which reviews the land reform policies in South Africa and its impact on youth employment and food security in the country. The main documents used in this paper are journal articles, official government gazettes, policy documents and media articles which are mostly secondary documents.

\section{Background to the land question}

The White Paper on South African Land Reform Policy (1997) alludes that land ownership has been a source of conflict over the years as a consequence of the history of conquest and dispossession, forced removals and racially skewed distribution of land resources. The Natives Land Act (Act No 27 of 1913) was promulgated by Parliament one hundred years ago in June 1913 and was only repealed in 1991. Van Onselen (2013) points out that the Natives Land Act was the first piece of legislation that made way for racial discrimination after the establishment of the Union of South Africa. Onselen (2013) adds that the act initially set aside $7.3 \%$ of all
South African land for "reserves" that was designed to accommodate "the native population". At the dawn of the new democratic dispensation in 1994, Onselen (2013) intimates that 600000 white commercial farmers who accounted for $1 \%$ of South Africa's population owned just less than $90 \%$ of the arable agricultural land.

The history of land ownership has serious implications for the way the different racial groups are able to access land, most especially in the rural areas for agricultural purposes. The Democratic Alliance (2013) also adds that the Native land Act of 1913 prohibited Africans from purchasing or leasing land outside the reserves created by the apartheid government. This law, the DA (2013), further explains set in motion the pattern of "dislocation and deprivation" which characterized property arrangements under the apartheid government. The DA (2013) notes just like Van Onselen (2013) that the Native Land Act of 1913 allocated approximately $87 \%$ of the land of the country to the exclusive ownership and use of the white population resulting into the Bantustan policy which relegated black citizens and once prosperous black farmers to a reserve of cheap, unskilled labor for white farmers and industrialists. The other laws which fortified and entrenched the dispossession of the indigenous black population of their ancestral land according to the DA (2013) include the Native Trust and Land Act of 1936 made the land in the reserves state land under the control of tribal chiefs; the Pegging Act of 1943 and the Asiatic Land Tenure and Indian Representation Act of 1946 which restricted the ownership of Indians to land in urban areas.

The Department of Rural Development and Land Reform (2013) observes that the reason the colonialists' targeted land of the conquered populations was to subdue them and turn them into vassals and slaves. The DRLR (2013) argues that the outcomes of the different Land Acts on the dispossession of the indigenous black population of land were the inability to produce enough food to feed themselves and their families; inability to rear animals; and having to survive on meagre and slave wages on white commercial farms and industries in towns.

It can be inferred from the discussions above that the dispossession of the indigenous population of land especially in the rural areas has, to a large extent, contributed to the high poverty, inequality and unemployment levels in the rural areas. Meanwhile the SABC (2016) quotes Luthando Mbinda, the leader of the Pan Africanist Congress (PAC) alluding to the fact that the land question was 
at the centre of the liberation struggle in South Africa in a parliamentary debate. The consequences of the dispossession of the majority of land as one of the main productive assets for the rural population are the grinding poverty, inequality, rural-urban migration, especially for the youth and the high rate of unemployment among black people in the country.

When the new democratically elected government came into power in 1994, it adopted a land reform policy that was aimed at addressing the wrongs of the past policies of apartheid and colonialism and dealing with socioeconomic challenges in the rural areas. Jacobs, Lahiff and Hall (2003) point out that South Africa's land reform hinges on three legs, namely: historical rights to land; tenure reform with land holdings and redistribution with aimed at transforming the racial pattern of land ownership. The Land Reform Policy Document (1997) indicates that the policy is aimed at addressing the following in both rural and urban environments:

- the injustices of racially-based land dispossession;

- the inequitable distribution of land ownership;

- the need of security of tenure for all;

- the need for sustainable use of land;

- the need for rapid release of land for development;

- the need to record and register all rights in property; and

- the need to administer public land in an effective manner.

The consequences of the Land Act restricted "natives" to owning just $13 \%$ of the land in South Africa which has not changed much nearly 21 years into democracy. The country is still battling with deracialization of land ownership. Mxotwa (2013) alludes that the government set a target of transferring $30 \%$ of the land (24.6 million) hectares of land to black communities by 2014 , but as at 2013, only 4 million hectares had been transferred so far. Meanwhile Walker (2008) points out that a national survey conducted in 2003 found that $85 \%$ of black South Africans agreed with the statement that "Most land in South Africa was taken unfairly by white settlers, and they, therefore, have no right to the land today". The ruling ANC government in South Africa, according to Walker (2008), positions the land question at the centre of its developmental agenda. The reason could be due to the prominence the issue is given in the Freedom Charter of 1955 to land and tenure security. Mwatwara (2013) is of the view that the landless people are increasing in South
Africa, where evidence shows that over two million farm dwellers, tenants on farms and independent producers were displaced between 1994 and 2004. The hunger and agitation for land from various groups and communities is getting louder every passing day which calls for all to attend to this pressing problem to avoid what happened in Zimbabwe few years ago, where the government in a chaotic way dispossessed the white commercial farmers of their farms which has led to serious famine and food insecurity for majority of the citizens of that country.

\section{The land reform policy}

Land has been a key question in South African history right from precolonial times through colonial times and the apartheid era to the new dispensation. Various wars were fought between the indigenous population and groups. Most of the indigenous people had conflicts with the colonists and the subsequent apartheid government over land. Two things are at the core of all anti-colonial struggles, namely repossession of land lost through deceit or force; and restoring the centrality of indigenous culture (Department of Rural Development and Land Reform (DRDLR), 2013). In the postapartheid era, the land question still remains a major source of political indelibility and development in the country. The question of food security or the otherwise of it and the high poverty levels, most especially, in the rural areas have been blamed on the scarcity of land for agriculture purposes. The DRDLR (2013, p. 6) notes that "the root of the land question today arises out of the pervasive process of land alienation that disposed the majority of South Africans of their land over the past few centuries". The Natives Land Act of 1913 was the first among the other many discriminatory laws that reinforced and entrenched the unjust dispossession of land from the indigenous population. The DRDLR states that laws which disposed blacks of land rights in the $19^{\text {th }}$ century led to a number of conflicts over the years to access to land, control of and, ultimately, ownership of land. The DRDLR adds that the 1913 Natives Land was reinforced by the 1936 Native Trust and Land Act, which gave only $13 \%$ of the land of South Africa for black occupation leading to the cruel and violent removal of black people and whole communities from their ancestral lands that had been declared white areas.

The new dispensation after 1994 took into account the unjust nature of how majority of the indigenous African population had been deprived of land as a consequence of the past racially discriminatory laws and practices. For example, Section 25 of the 
Constitution of South Africa (1996) promises land reform that entitles those who have historically been deprived of property "as a result of past discriminatory laws or practices" access to this valuable resource. It can be argued that the lack of access to arable land has fuelled poverty and high incidence of unemployment in rural South Africa. Citing the National Planning Commission (2011), Kepe and Tessaro (2012) intimate that nearly $40 \%$ of South Africa's population resides in the rural areas, while they at the same time account for $70 \%$ of the country's poor population.

The three phases of land reform in post-apartheid South Africa can be classified as phase 1 - 1994 1999; phase 2 - 1999 - 2007 and phase 3 - the postPolokwane era 2007 to date. Phase 1 of land reform in South Africa, according to Greenberg (2013, p. 9) "was basically designed to get groups of former disposed people onto the land, using the Settlement and Land Acquisition Grant (SLAG)". The approach, normally referred to as restitution was to purchase commercial farms on sale by willing farmers for transfer to beneficiaries. This was an attempt to return people to the land they were forcefully removed from by the apartheid regime in the past. The mechanism seems not to have worked very well because of financial constraints, beneficiaries being in groups and not as individuals and lack of support for infrastructure for the beneficiaries.

The second phase during the Mbeki era - 19992007, according to Greenberg (2013), moved away from the welfare-type group projects which characterized the first phase towards an approach on land reform for commercial production. This approach, according to Greenberg (2013), took the form of Land for Agricultural Development (LLRAD) program which placed emphasis on individual and household beneficiaries for redistribution. The approach took a more entrepreneurial which required beneficiaries to cofinance projects with limited government support. This approach was criticized by some development practitioners and labor groups for creating a small elite at the expense of the expected broad-based black economic empowerment through agricultural and land reform.

The post-Polokwane era - 2007 to date land reform by Greenberg (2013) account took cognizance of the twin problems slow land redistribution and the lack of productive use of land. The "willing buyer, willing seller" model has been blamed to a large extent on the slow rate of land reform, while the lack of optimal use of productive land acquired under the land reform process may be attributed to factors such as the lack of infrastructure and lack of skills among other bottlenecks. Greenberg quotes the Minister of Rural Development and Land Reform Gugile Nkwinti who said "more than $90 \%$ of [land reform projects] are not functional, they are not productive. The land has been given to people and they are not using it. No country can afford that" (quoted in SAPA, 2010). The observation above could be true and is most likely having negative impact on food production and food security, but there may be the need for proper investigation to be conducted to find out the reasons for the lack of productive use of the land by some beneficiaries. The post-Polokwane era land reform phase called for the pursuit of a small-scale farmer strategy as a way to rapid land reform called the Proactive Land Acquisition Strategy (PLAS) which permits the state to buy and hold it for transfer.

\section{Progress made so far on land reform and challenges}

The new government has chalked some progress on land reform through various legislative and other policies, programs and strategies. As indicated earlier on in this article, land reform comprises three elements, namely, restitution, redistribution and tenure reform. Land reform revolves around dispossession and land alienation emanating from the 1913 Natives Land Act of 1913 which is addressed in South Africa's current Constitution. For example, the following are some of the sections that deal with the issue:

Section 25(5) of the Constitution states that:

The state must take reasonable legislative and other measures, within its available resources, to foster conditions which enable citizens to gain access to land on equitable basis.

Section 25(6) of the Constitution states that:

A person or community whose tenure of land is legally insecure as a result of past racially discriminatory laws or practices is entitled, to the extent provided by an Act of Parliament, either to tenure which is legally secure, or comparable redress.

On communities and communities dispossessed of the property after 1913, Section 25(7) states that:

A person or community disposed of property after 19 June 1913 as a result of past racially discriminatory laws or practices is entitled, to the extent provided by an Act of Parliament, either to restitution of that property or to equitable redress. 
Pepeteka (2013) notes that although the Constitution makes provision for land reform, the right to own property is also protected thereby creating tension between the rights of existing property owners and realizing the rights of those rights to property have been denied due to discrimination. The Restitution Program makes provision through the Restitution of Land Act, 1994 (Act No. 22 of 1994) to return land or compensation to people who were disposed of their land through discriminatory laws since 1913. Those who wanted to make claims were given up to December 1998 to make their submissions. Citing DRDLR, Pepeteka (2013) alludes that 97\% of the total claims had been settled by January 2013. Pepeteka notes with grave concern that most of the claims that have been settled have been financial compensation rather than with land which the rural poor desperately needs for their livelihoods on sustainable basis. A number of challenges have bedevilled the Restitution Program which, according to Pepeteka (2013), includes: understaffing at the Commission and staff turnover; dealing with fraudulent claims; conflict among rural claimants; challenges and protracted negotiations and opposition by land owners, as well as inflated prices of land and untraceable claimants.

The redistribution aspect of land reform seeks to address the legacy of racial inequality in accessing land and creating opportunities for development and also makes provision for blacks to have access to land for residential and productive use in order to improve their livelihoods. The provision for this is in Section 25(5) of the Constitution. The government, according to Pepeteka (2013), committed itself to redistribute $30 \%$ of white-owned agricultural land to poor and land over by 2014 in 1994 on the "willing buyer/willing seller" principle. By 2012, only $7.5 \%$ of the target had been met which President Zuma in his State of the Nation Address in 2013 indicated cannot be met in 2014. Some of the challenges that have plagued land reform in post-apartheid South Africa include the "willing buyer-willing seller" principle where it is alleged has led to prices of farms and land being exaggerated; foreigners with the resources acquiring some of the land; unwillingness of land owners to sell their land; limited arable land for agriculture and the lack of support for beneficiaries of land reform.

Pepeteka (2013) is of the view that land tenure reform under land reform has fared the worst among the three pillars. She points out that the main achievement has been legislative provisions which include the Extension of Security of Tenure Act (ESTA), Land Reform (Labor Tenants) Act, 1996
(Act No. 3 of 1996) and the Interim Protection of Informal Land Rights Act (IPILRA), 1996 (Act No. 31 of 1996).

Evans (2013) argues that the mechanism that has been used for addressing land reform in post apartheid South Africa has been based on what he refers to as the transitional justice model which focuses to a large extent upon individual violations of a narrow set of civil and political rights and provision of legal and quasi-legal remedies such as the truth and reconciliation, amnesties and prosecutions. Furthermore, Evans (2013) is of the view that a crucial aspect of the transformational justice agenda is its focus on socio-economic structures, the ways in which inequalities may produce structural violence and how this structural violence may be addressed effectively. Meanwhile, Daly (2002) argues that transition may be seen as a change "at the top", based on "elite bargains", while transformation can be viewed as more and far reaching change throughout society. Daly (2002) notes that [t]ransition suggests movement from one thing to another - from oppression to liberation, from oligarchy to democracy, from lawlessness to due process, from injustice to justice. Transformation, however, suggests that the thing that is moving from one place to another itself is changing as it proceeds through the transition; it can be thought of as a radical change.

It is clear that South Africa's land policy has to a large extent been based on the transitional justice model and has not been able to address the past socio-economic injustices and the inequality in the country adequately contributing to some of the socio-economic challenges such as poverty, inequality, rural urban migration, inequality, farm murders and attacks just to name a few.

\section{Food security, land reform and the youth}

South Africa has been a net food exporter for many decades until quite recently. Stuart (2013) avers that the country is now a net food importer. There are a number of reasons that have been assigned to this state of affairs including policy uncertainties regarding land reform, increasing mechanization and migration of commercial farmers to other countries, as well as the increasing cost of farming inputs and labor costs. The number of commercial farmers has been dwindling over the past two decades. Stuart (2013) intimates that over the past twenty years the number of commercial farming units has reduced from approximately 60,938 in 1996 to 39,982 in 2007 and an estimated 30000 in 2012, which translates to about $50 \%$ decline. In addition to that, Goldblatt (2011) observes that the 
land reform program which has addressed some of the past injustices has also led to declining production in the sector, as about $90 \%$ of the land given to emerging black farmers have failed resulting in lower agricultural output in certain areas. She adds that the uncertainty around land tenure has also proved to be a disincentive for white commercial farmers. Goldblatt (2011) adds that food prices which have hitherto remained relatively stable over the years have started to increase due to transport, electricity and input cost. Rising cost of food affects the poor the most who are estimated to spend about $33 \%$ of their income on the average on food. All the factors mentioned above negatively impact on food security. Goldblatt argues that food security is not only about the available of food and their prices, but also affects unemployment. She alludes that agriculture's contribution to employment in South Africa fell by $75 \%$ between 1993 and 2005.

Despite the fact the agricultural production is on the decline, the population of the country, according to Goldblatt (2011), is growing at $2 \%$ per annum. The population of South Africa in Goldblatt's projections is expected to grow to 82 million by the year 2035 from the current 52 million. This implies that the country's agricultural production has to almost double to cater for the growing population which is increasingly becoming affluent or that has to be supplemented by imports.

A lot of efforts and energy have been put on addressing issues pertaining to land reform and food security in legislative, policies and strategies, but the author is of the view that one important group of people has been left out in the whole equation on land reform and food security which is the youth. This section of the article discusses the role of the youth in land reform and food security for South Africa. The National Development Plan (NDP) (2013) notes that the agricultural sector has the potential to create 1 million new jobs by 2030 as a major contributor to job creation in the rural areas. To achieve this, the country is expected to:

- expand irrigated agriculture;

- use some of its underused land in communal areas and land reform projects for commercial production;

- create backward and forward linkages in the agricultural value chain;

- develop strategies that give new entrants access to product value chains and support from betterresourced players.
Meanwhile, not much is said about the role of the youth in all this, as the NDP addresses the issues on land reform and food security. Some of the challenges the country faces in both the rural and urban areas are partly due to rural urban migration, as opportunities are limited, most especially for the rural youth. One is of the view that placing emphasis on the rural youth and supporting them in agriculture will go a long way in addressing youth unemployment, rural-urban migration and food security in South Africa. Meanwhile, the United Nations Education and Scientific Organization (UNESCO) (2012) advocates that governments should develop policies and programs that aim at youth in deprived rural areas. It adds that $70 \%$ of the world's 1.4 billion people living in extreme poverty live in the rural areas are involved in small scale farming. UNESCO (2012) emphasizes that greater attention has to be given to skills development of young people to acquire foundation skills, training in agricultural techniques to enhance their productivity. Furthermore, it suggests that youth living in rural areas, who have particularly been disadvantaged by a lack of access to land, financial assets and educational opportunities should be afforded an integrated package of support that should include training in entrepreneurial and business skills to enable them to expand their livelihood options through non-farm work. Meanwhile, the National Youth Development Agency (NYDA) (2015) makes policy proposal to government on the economic participation and transformation for the youth that includes reducing South Africa's high levels of youth unemployment by pursuing policies and strategies in the economy that focus on a labor-absorbing growth path which agriculture can be a major player. On rural development and land reform for young people, the NYDA (2015) notes that the youth living in rural areas, in most cases, struggle to meaningfully participate in the economy of the country as a result of lack of access to or availability of land, and poor economic and social infrastructure and calls for interventions to promote and support and support youth participation in the agricultural sector to address issues such as access to land, implements and inputs, business skills, access to information, opportunities and markets.

Although the NDP (2012) notes the potential of agricultural development based on successful land reform, employment creation and environment safeguards, not much is said about the youth in agriculture as a strategy for youth development and addressing the challenges of poverty, unemployment, rural-urban migration and food security in the rural areas. The author of this article 
is of the view that addressing the land reform is important, but it should simultaneously address youth unemployment and food security in the country seriously. For Stuart (2013), South Africa's food security is under threat, as the average age of commercial farmers in South Africa is over 60 years, while the white farmers, according to Goldblatt (2011), are not motivated to farm responsibly because of uncertainties surrounding land reform in general, and land tenure reform, in particular.

\section{Conclusion}

At first, the land question which has caused a lot of socio-economic problems for South Africa came into being from the history of conquest, colonialism and apartheid. After the demise of apartheid, laws, policies and various approaches and strategies were put in place to address the land reform which was based on three legs, namely, restitution, redistribution and land tenure reform. All of these have had their successes and challenges, but there is the general consensus among large sections of South Africans that the implementation of the policies has not worked as planned. A lot of people and organizations believe that the "willing buyer, willing seller" principle which is demand driven and to a large extent based on the transitional justice continues to promote inequality in the country. The policy uncertainties surrounding future land reform, most especially, for white commercial farmers have resulted in less investment in agriculture. Besides that, most of the beneficiaries of land reform to a large extent have not succeeded in putting the land into productive use for one reason or the other. All these have culminated in a number of problems including threat to future food security, inequality, poverty and unemployment among others for the country. In trying to address the issues on land reform and food security and the accompanying problems related to them, the youth which is the future of every nation appears to have been left out of the equation. The position of this article, therefore, is that while the role land reform, food security and sustainability cannot be over emphasized, these should not be done without the involvement of the youth. The youth, most especially, in the rural areas who show interest in agriculture should be identified, trained, supported and mentored and prepared to take over from the aging white commercial farmers to ensure that land reform and food security programs succeed.

\section{References}

1. Daly, E. (2002). Transformational Justice: Charting a path to reconciliation, International Legal Perspective, 12 (1/2), pp. 73-183.

2. Democratic Alliance. (2013). DA policy on land reform, December 2013.

3. Department of Rural Development and Land Reform. (2011). The Green Paper on Land Reform 2011.

4. Department of Rural Development and Land Reform. (2013). Strengthening the relative rights of people working the land, Draft Policy Proposals, 30 July 2013.

5. Evans, M. (2013). Land, socio-economic rights and transformational justice. Paper presented at Land Divided: Land and South African Society in 2013, in Comparative Perspective Conference, 24-27 March 2013. University of Cape Town.

6. Extension of Security of Tenure Act No. 62 of 1997. Cape Town.

7. Goldblatt, A. (2011). Agriculture: Facts \& trends South Africa. WWF-SA.

8. Greenberg, S. (2013). The disjuncture of land and agricultural reform in South Africa: Implications for the agricfood system. University of the Western Cape. South African Institute for Poverty and Agrian Studies: Working paper No. 26.

9. Jacobs, P., Lahiff, E. and Hall, R. (2003). Evaluating land and agrarian reform in South Africa. Program for Land and Agrarian Studies (PLAAS). University of the Western Cape. Occasional papers.

10. Kepe, T. and Tessaro, D. (2012). Integrating food security with land reform: A more effective policy for South Africa, CIGI-Africa Policy Brief, 4.

11. Land Reform (Labour Tenants) Act No. 486 of 1996. President's Office. Pretoria, South Africa.

12. Mogalakwe, M. (2006). The use of documentary research methods in social research, African Sociological Review, 10(1), pp. 221-230.

13. National Planning Commission. (2011). The National Development Plan. The Presidency, Republic of South Africa.

14. Mwatwara, W. (2013). The politics of land reform: A comparative study of South Africa and Zimbabwe in the post 1994 era. Paper presented at the Conference on, Land Divided: Land and South African society 2013, in Comparative Perspective', University of Cape Town, 24-27 March 2013. Work in progress.

15. Mxotwa, M. (2013). Racial steps needed to right the 1913 wrong. Sunday Times, 23 June 2013, p. 18.

16. National Development Plan. (2012). National Development Plan 2030. Executive Summary.

17. Natives' Land Act, 1913 (Act No. 27 of 1913). Pretoria, South Africa.

18. NYDA. (2015). National Youth Policy 2015-2020. The Presidency, Republic of South Africa.

19. Payne, G. and Payne, J. (2004). Key concepts in social research. London: Sage Publications. 
20. Pepeteka, T. (2013). Reversing the legacy of the 1913 Natives Land Act: Progress of Land Reform. Parliament of Republic of South Africa.

21. Restitution of Land Rights Act No. 22 of 1994. Pretoria, South Africa.

22. SABC. (2016). Land struggle was the centre of liberation struggle. Available from: http://www.sabc.co.za/news/a/ecd9/c9804/c8d4/aebad/41af2e33d6c236/\%E2\%80\%98Land-struggle-was-atcentre-of-liberation-struggle\%E2\%80\%99-20162704. Accessed at 2015/12/18.

23. SAPA. (2010). Land reform beneficiaries owed R3.4bn by government. Available from: http://mg.co.za/article/2010-07-05-land reform-beneficiaries-owed-r34bn-by-govt. Accessed on 2016/05/20.

24. South Africa, Republic. (1996). Constitution of the Republic of South Africa, 1996.

25. South Africa, Republic. (1997). White paper on Land Reform Policy. Department of Land Affairs.

26. South Africa Yearbook. (2010). Rural development and land reform.

27. Stuart, J. (2013). Land reform in South Africa - so, what is the REAL problem? Accessed from: http://www.sagoodnews.co.za/newsletter_archive/land_reform_in_south_africa_s0_what on 10/07/2013.

28. UNESCO. (2012). Youth and skills: Putting education to work. EFA Global Monitoring Report. Paris.

29. Van Onselen, G. (2013). Consequences of a cruel act linger on. Sunday Times, 23 June 2013, p. 18.

30. Walker, C. (2008). Landmarked: Land claims and restitution in South Africa. Johannesburg: Jacana. 